\title{
D. Medaković \\ Carbonic anhydrase activity and biomineralization process in embryos, larvae and adult blue mussels Mytilus edulis $\mathbf{L}$.
}

Received: 28 November 1998 / Received in revised form: 30 August 1999 / Accepted: 31 August 1999

\begin{abstract}
To decide whether a physiological role can be attributed to enzymatic activity with respect to crystal formation and biomineralization of the first larval shell, carbonic anhydrase (CA) activity was measured in embryos and larvae of the blue mussels Mytilus edulis L. Also, CA activity was determined in the mantle edge and gonads of adult mussels with different shell length and condition index. The intention was to find a possible correlation between CA activity and adult shell calcification, i.e. gonadal maturation. The comparison of CA activity in different developmental stages of mussels and the results of an X-ray diffraction study of biomineralization processes in embryonic and larval shells indicate that CA activity is maximal at the end of several developmental stages. Consequently, the increase in CA activity precedes some physiological changes, i.e. the somatoblast $2 \mathrm{~d}$ formation and the occurrence of the first calcite and quartz crystals in embryos, shell field formation in the gastrula stage, shell gland and periostracum production in trochophores, and rapid aragonite deposition in larval prodissoconch I and prodissoconch II shells. Furthermore, it was found that in adult mussels CA activity was quite variable and that in the mantle edge it was frequently inversely related to the activity in the gonad.
\end{abstract}

Key words Mytilus edulis L. C Carbonic anhydrase (CA) activity - Biomineralization process - Shell development . Biomineralization curves

\section{Introduction}

The enzyme carbonic anhydrase (CA) catalyses the reversible hydration of $\mathrm{CO}_{2}$ to $\mathrm{HCO}_{3}^{-}$and $\mathrm{H}^{+}$. This zinc

Communicated by H.-D. Franke

D. Medaković (

Ruđer Bošković Institute, Center for Marine Research Rovinj, Giordano Paliaga 5, HR-52210 Rovinj, Croatia

e-mail: medakovic@cim.irb.hr

Tel. +385-52-811-544, Fax: +385-52-813-496 metaloenzyme accelerates bicarbonate formation and plays an important role in several physiological functions: respiration, ion transport, acid-base regulation, and biomineralization. The activity of CA and its influence on physiological functions in Mollusca have been examined by many authors (Wilbur and Anderson 1950; Kawai 1955; Freeman 1960; Nielsen and Frieden 1972; Wilbur and Saleuddin 1983; Erlichman et al. 1994; Miyamoto et al. 1996). However, the effect of CA activity on biomineralization processes in adult bivalve shells as well as in the early larval stages have been insufficiently studied so far (Medaković and Lucu 1994; Medaković 1995). In the present study, CA activity was measured at different developmental stages, as well as in the gonads and the mantle edge of adult specimens of Mytilus edulis, in order to clarify the possible physiological role of CA activity in crystal formation and biomineralization processes.

\section{Materials and methods}

Adult blue mussels, M. edulis, with different shell lengths (48$67 \mathrm{~mm}$ ) were collected from the rocky shore of the island of Helgoland, North Sea, Germany. The mussels were conditioned to obtain mature gonads and to induce spawning. The conditioning stimulus was a daily temperature increase of $1{ }^{\circ} \mathrm{C}$, from $14^{\circ} \mathrm{C}$ up to $18^{\circ} \mathrm{C}$, followed by a return to the initial conditioning temperature. Such a thermal conditioning treatment was repeated regularly for 3 weeks. Animals were induced to spawn using a combined thermal-mechanical stimulation (Loosanoff and Davies 1963; Hrs-Brenko and Calabrese 1969). Mature eggs were fertilized by adding a drop of sperm to the egg suspension. Fertilized eggs were reared in a 3-1 beaker, filled with $0.45 \mu \mathrm{m}$ filtered seawater of $30.0 \mathrm{ppt}$ salinity and at $18^{\circ} \mathrm{C}$. The starting densities of each culture ranged from 1000 to 5000 eggs $1^{-1}$ of seawater. The water was changed every 2 days, using a $40-\mu \mathrm{m}$ sieve, irrespective of embryo or larval size. Different developmental stages were separated by means of sieves of 40-, 80- or $120-\mu \mathrm{m}$ mesh size, at the beginning every $30 \mathrm{~min}$ and later every few hours. After filtration the contents of each sieve were resuspended in a small volume, then classified by means of optical microscopy. Average length of embryos and larvae, respectively, was calculated after measuring 50 or more specimens in each sample. Each sample was divided into two subsamples, one for measuring enzymatic activity and the other for examination of mineral components. 


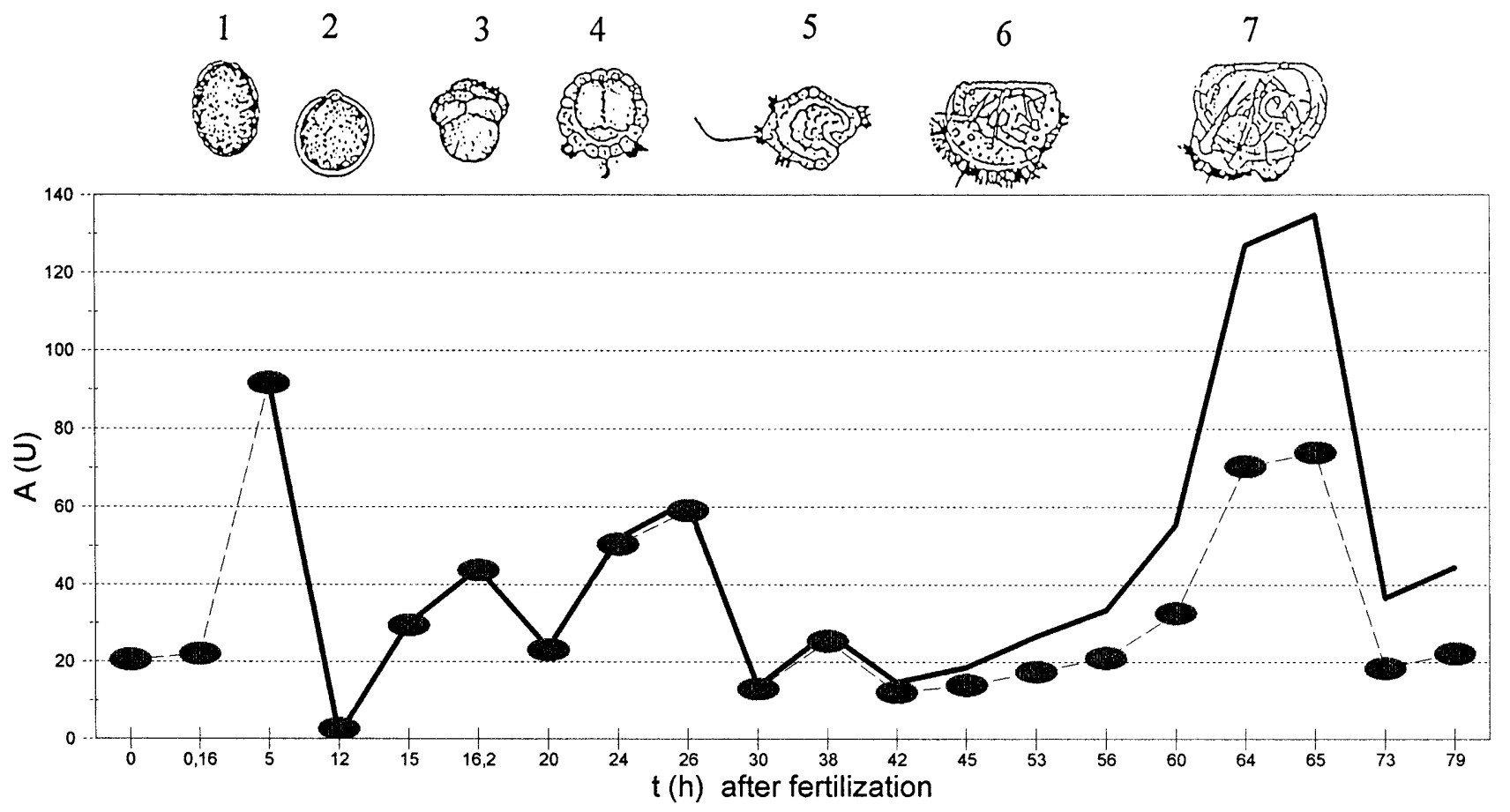

Fig. 1 1-7 Development of Mytilus. edulis according to Arakawa (1980), Strathmann (1987) and Kulakowski and Fliatchinskaya (1993): 1 unfertilized egg; 2 fertilization; 3 secondary 2d somatoblast formation; 4 transition stage from late gastrula to early trochophore; 5 fully developed trochophore; $6 \mathrm{D}$-shaped or straight hinge veliger with prodissoconch I shell; 7 prodissoconch II. Curves show carbonic anhydrase (CA) activity $A$ at different developmental stages of $M$. edulis, expressed as CA units (U) per $g$ of wet weight of sample. A CA activity in whole samples. According to biomineralization curves (Fig. 2) correction of results for weight percent of shell in samples was carried out and corrected CA activities are represented by bold curve $A *$

The shell length of another group of adult mussels was measured, and soft tissues and shells were weighed separately. After determination of the condition index (Baird 1985; Davenport and Chen 1987), the parts of the edge of the mantle and gonadal tissue were dissected and briefly air dried on filter paper. The dissected tissues were stored in vials at $-80^{\circ} \mathrm{C}$ before weighing. The shells were carefully cleaned from the remaining soft tissues, washed with distilled water, air dried and stored before analysis.

\section{Measurement of CA activity}

The samples of mussel embryos and/or larvae were placed in plastic vials and centrifuged for $3 \mathrm{~min}$ at $600 \mathrm{~g}$. The superfluous suspension was carefully decanted, and the samples were weighed and stored at $-80^{\circ} \mathrm{C}$.

Before measurement of the enzymatic activity, samples of embryos, larvae and adult mussel soft tissues were thawed and solubilized with $6.125 \mathrm{ml}$ Triton X-100 per $1 \mathrm{~g}$ wet weight (ww), homogenized and stored at $0^{\circ} \mathrm{C}$. The activity of CA was measured by a micromethod developed by Maren (1960) and modified by Bruns et al. (1986). The activity $(A)$ of CA was expressed by the uncatalysed reaction time $\left(t_{0}\right)$ and the catalysed reaction time $\left(t_{\mathrm{enz}}\right)$, using the following equation: $A=\left(t_{0} / t_{\mathrm{enz}}\right)-1$. One unit (U) of $\mathrm{CA}$ activity was defined as the enzyme activity required in the final assay volume to halve the uncatalysed reaction time $\left(t_{0}=2 t_{\text {enz }}\right)$.

\section{$A^{*}-A$}

The CA assays of each sample were performed in triplicate and averaged. Before and after each series of samples, the uncatalysed time was measured and, for the interpretation of results, a daily average was used (e.g. $t_{0}=60.1 \pm 2.2 ; n=71$ ). The results are expressed as CA units (U) per milligram of wet weight of the sample.

Preparation of samples for X-ray diffraction

Preparation of embryos and larval mussels for X-ray diffraction depended on the sample quantity (Medaković et al. 1989, 1997; Medaković and Lucu 1994; Medaković 1995). After collection, each sample was washed with distilled water and dried at room temperature. When the amounts of some embryonic and larval samples were too small to fill the sample holder, they were transferred by a pipette onto the centre of the sample holder, carefully powdered, spread uniformly, and glued to prevent a dispersion of powder during the X-ray diffraction experiment.

Samples of adult mussel shells were powdered in an agate mortar and placed on the sample holder. Diffraction patterns were taken by means of an X-ray counter diffractometer (Philips, MPD 1880 ), equipped with a vertical goniometer and proportional counter, using monochromatized $\mathrm{CuK} \alpha$ radiation. Calcite and aragonite were identified according to the JCPDS, Powder Diffraction File, cards no. 5-453 for aragonite and 5-586 for calcite. The fractions of each mineral phase were determined by application of quantitative X-ray diffraction phase analysis (Popović and Gržeta 1979; Popović et al. 1983).

\section{Results}

Figure 1 shows the CA activity in embryos and larvae of M. edulis. The enzymatic activity ranged from $A=0.2 \times$ $10^{-3} \mathrm{U} \mathrm{mg}^{-1}$ ww in the embryos to $A=136.0 \times 10^{-3} \mathrm{U} \mathrm{mg}^{-1}$ ww in the larvae $65 \mathrm{~h}$ after fertilization. The biomineralization curves (Fig. 2) of embryonal and larval M. edulis, 
Fig. 2 Mytilus edulis. Biomineralization curves. Variation of fractions of amorphous tissue, calcite, aragonite and quartz during development. Immediately after fertilization only soft tissue, the amorphous phase, is observed. Five hours later, embryos which have developed a secondary $2 \mathrm{~d}$ somatoblast contain $1.5 \%$ calcite and $1 \%$ quartz. Mussel larvae $72 \mathrm{~h}$ after fertilization have mostly aragonitic shells, mineral composition is constant, and prodissoconch II shell has been formed

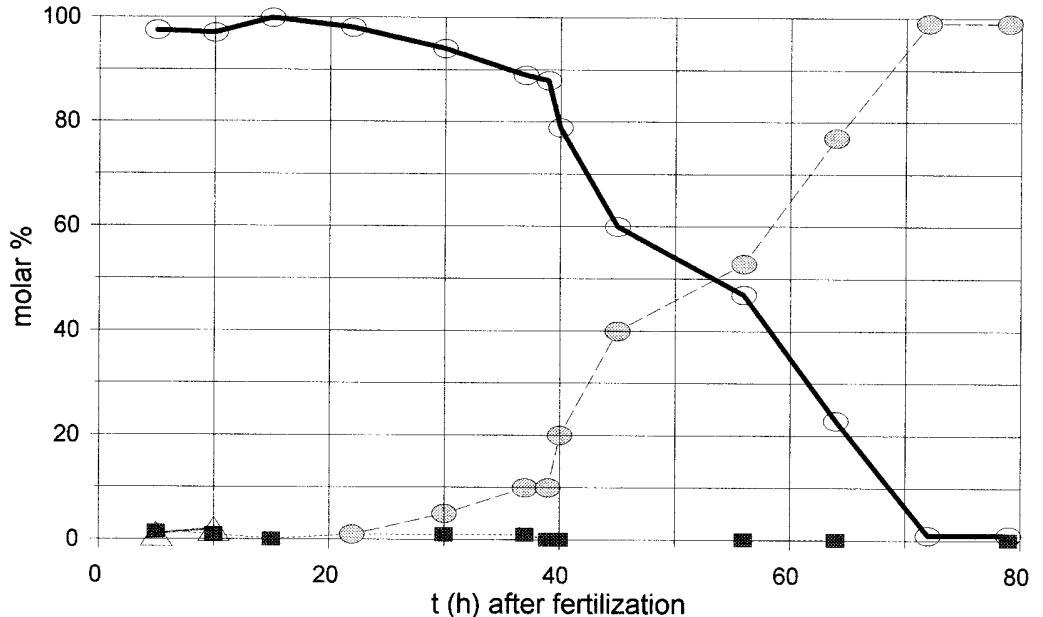

$\succ$ Amorphous ….... Calcite
- Aragonite $\$ Quartz constructed according to diffractograms obtained by Xray diffraction, show that some later embryonic and all larval samples contained inorganic components, i.e. minerals of the first shells. These samples were not decalcified in order to prevent a possible chemical influence on CA activity. To express real activities in soft tissues, a correction of results for the weight percent of shells was required and presented by a bold curve in Fig. 1.

The enzymatic activity of the mantle edge of adult mussels ranged from $A=58.3 \times 10^{-3} \mathrm{U} \mathrm{mg}^{-1}$ ww (shell length $60 \mathrm{~mm}$ ) to $A=327.0 \times 10^{-3} \mathrm{U} \mathrm{mg}^{-1} \mathrm{ww}$ (shell length $56 \mathrm{~mm}$ ). The CA in mussel gonads had lower minimal $A=7.0 \times 10^{-3} \mathrm{U} \mathrm{mg}^{-1} \mathrm{ww}$ and higher maximal activities $A=415.0 \times 10^{-3} \mathrm{U} \mathrm{mg}^{-1} \mathrm{ww}$ than those measured in the mantle edges. However, the average activity in gonads, $\left(A=208.5 \times 10^{-3} \mathrm{U} \mathrm{mg}^{-1} \mathrm{ww}\right)$ was higher than in the mantle epithelium $\left(A=167.5 \times 10^{-3} \mathrm{U} \mathrm{mg}^{-1} \mathrm{ww}\right)$. Figure $3 \mathrm{a}$ shows the CA activity in both the mantle edge and the gonads as a function of shell length. A comparison of CA activity and the condition index in gonads and the mantle edge is presented in Fig. $3 \mathrm{~b}$.

\section{Discussion}

In the recent literature, except for preliminary results (Medaković and Lucu 1994; Medaković 1995), no data are available on CA activity in embryos, larvae and adult M. edulis. Consequently, to interpret the results appropriately, a thorough discussion of literature data related to other molluscs, especially bivalve species, and certain hypotheses on biomineralization processes and possible CA activity influence on biomineralization of bivalve shells is indispensable.

The present results indicate that average CA activity in mussel embryos and larvae was approximatively fourfold lower than in the adult mantle edge and fivefold lower than in the gonadal tissue. In contrast, Wilbur and Anderson (1950), reported that in snail larvae of Busy- con carica the CA activity increased 47-fold at the beginning of shell formation in comparison to adults. Nielsen and Frieden (1972) stated that the great difference in CA activity between oysters Ostrea equestris and Crassostrea virginica may be caused by particular physiological or environmental differences between the two species. Physiological and ecological differences between the gastropod Busycon carica and the mussel $M$. edulis may also explain the relatively high differences in enzymatic activity between these two species. Also, although CA activities in embryos and larvae of M. edulis are lower than in adult mussel tissues, a significant increase in enzymatic activity in some developmental stages (Fig. 1) confirmed the findings of Wilbur and Anderson (1950), indicating a connection between CA activity and shell formation. The same authors assumed that CA activity is not constant but may be altered by physiological changes in the organism. The results of the present study are strongly in accordance with this assumption. The comparison of CA activity in different developmental stages (Fig. 1) and the biomineralization curves of embryos and larvae (Fig. 2) indicate that CA activity reached a maximum at the end of each developmental stage connected with biomineralization. Unfertilized eggs have low CA activity, but immediately after fertilization CA activity slowly increases. During later cell division, the first CA activity maximum is reached $5 \mathrm{~h}$ after fertilization. Strathmann (1987) and Lutz and Kennish (1992) reported that $5 \mathrm{~h}$ post-fertilization mussel embryos have 16-32 cells. Kulakowski and Fliatchinskaya (1993) noted that M. edulis embryos $5 \mathrm{~h}$ after fertilization have only 8 cells. The present study shows that immediately after the first CA maximum embryos had 12 cells and the first somatoblast $2 \mathrm{~d}$ was formed. According to Verdonk and Cather (1983), the 2d somatoblast and in some rare cases the $2 \mathrm{c}$ somatoblast are the only cells in the embryo forming the initial shell field, the shell gland and at least the first shell. Also, the biomineralization curves (Fig. 2) show that in such em- 
Fig. 3 Mytilus edulis. Carbonic anhydrase activity $(A)$, expressed as CA units $(U)$ per $g$ of wet weight of sample in both mantle edge and gonad of adult mussels as a function of shell length (a) and condition index (b). Activity in the mantle edge is frequently inversely related to activity in the gonad

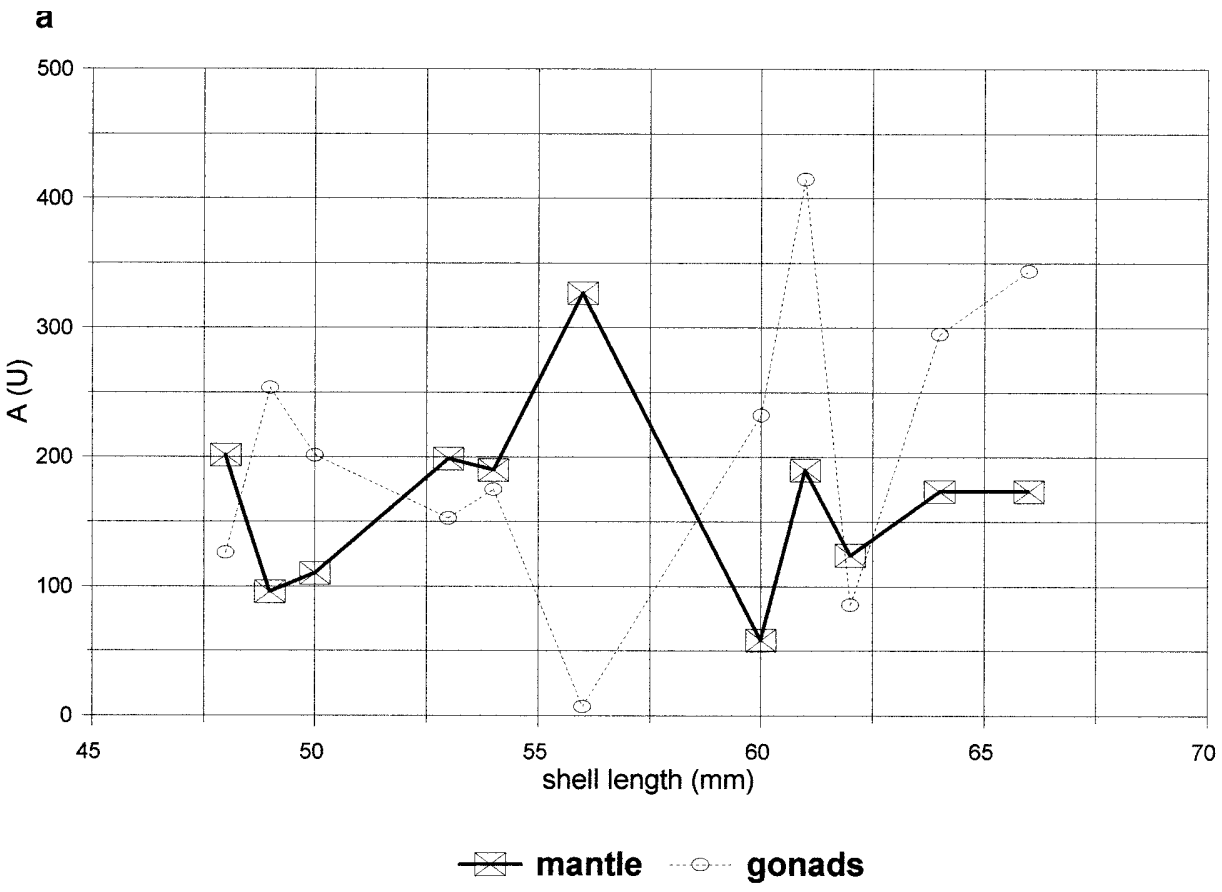

b

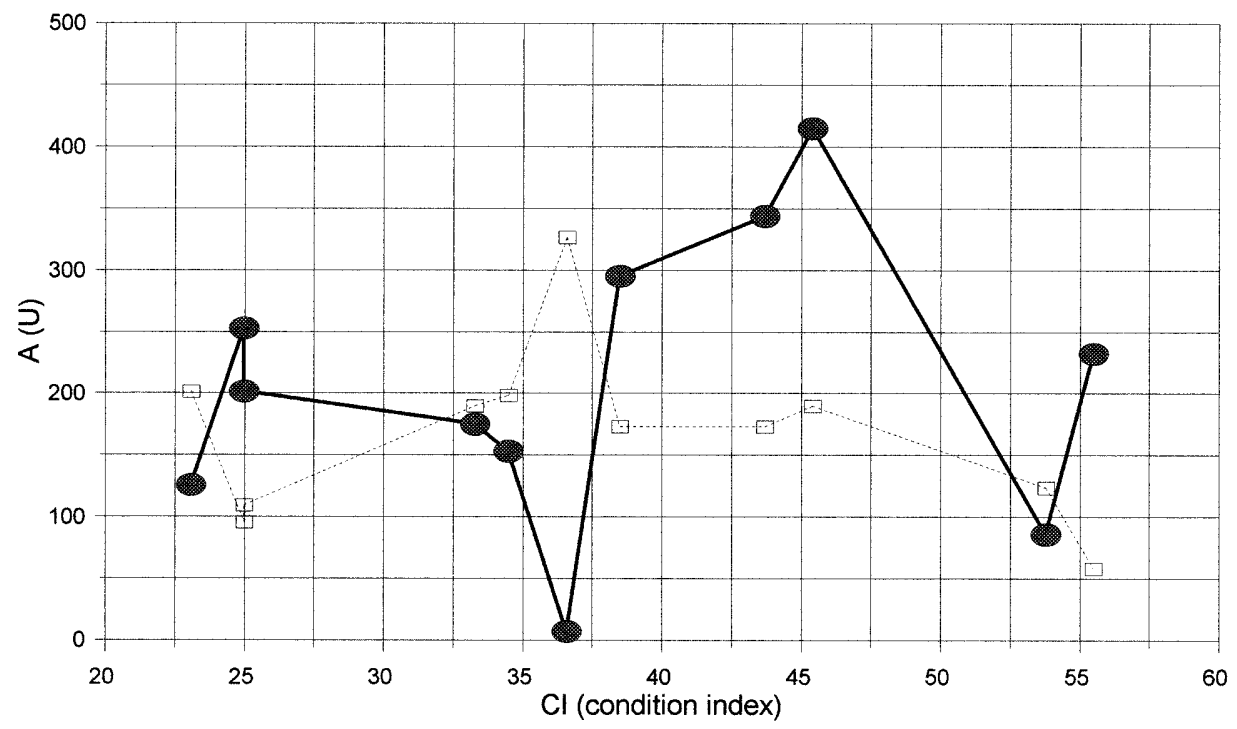

$\because \cdots$ mantle gonads

bryos the first mineral components are present, i.e. calcite in amounts of 1.5 molar $\%$, and quartz $1 \%$, respectively. The occurrence of small calcite amounts in mussel embryos is expected since a similar quantity of calcite was found in embryos of the Mediterranean mussel Mytilus galloprovincialis and oyster Ostrea edulis (Medaković et al. 1989, 1997; Medaković 1995). Calcite crystals play a role in the further development of larval shells, acting as aragonite crystallization centres. Small quantities of mineral quartz were also found in early embryos of M. galloprovincialis (Medaković 1995). It is known that quartz and some other minerals can be incorporated into or "captured" in adult molluscan shell layers during rapid shell growth or as the result of some disturbances in the biomineralization processes (Carriker et al. 1982; Medaković 1995). Nevertheless, the presence of this mineral in embryos of both Mytilus species remains to be explained.

After formation of the first somatoblast 2d, CA activity rapidly decreases and reaches its lowest value in the blastula, $7 \mathrm{~h}$ after fertilization (Fig. 1). During gastrulation, CA activity again increases and reaches a further 
maximum $16 \mathrm{~h}$ after fertilization, indicating shell gland formation in the late gastrula stage. In this period the biomineralization curves show a dominance of the organic-amorphous component; calcite is present in small amounts and quartz is not recorded (Fig. 2). In the subsequent developmental period, during transition from gastrula to early trochophore, an increasing CA activity immediately precedes the formation of the shell field, which is situated on the posterior side of the trochophore (Kniprath 1979, 1981). Later during the invagination process, the shell field forms the prechonchiolin gland of the outer noninvaginated cells. This gland secretes the first organic periostracum, i.e. the beginning of the prodissoconch I shell (Kniprath 1979; Waller 1981; Kasyanov 1984). The periostracum can be detected by optical microscopy in a trochophore $26 \mathrm{~h}$ after fertilization (Fig. 1), although biomineralization curves show that mineralization of the first periostracum, characterized by the first appearance of aragonite crystals, has already begun in the trochophore $22 \mathrm{~h}$ after fertilization (Fig. 2). In the oyster $O$. edulis, appearances of the first aragonite crystals indicate a transitional phase between late trochophore and early veliger (Medaković et al. 1997). These results show that in M. edulis, although calcification of the periostracum begins earlier, the first veliger larvae are formed $38 \mathrm{~h}$ after fertilization. This is in accordance with the findings of Kulakowski and Fliatchinskaya (1993), who reported that the first veligers of M. edulis are formed 30-34 h after fertilization. The later CA activity increase (Fig. 1) followed by a rapid aragonite increase and proportional soft tissue weight decrease (Fig. 2) shows that prodissoconch I shell formation is completed in veliger larvae $55 \mathrm{~h}$ after fertilization, while the prodissoconch II shell is formed $72 \mathrm{~h}$ after fertilization (Figs. 1, 2). Waller (1981) noted that the formation of prodissoconch II shells of the oyster $O$. edulis begins immediately after the formation of the prodissoconch I, the shell of which encloses the whole larval body. This statement is confirmed by an intensive CA activity increase in the period of prodissoconch I to prodissoconch II formation (Fig. 1), and also by a rapid aragonite increase (Fig. 2).

High CA activity precedes physiological changes and biomineralization processes during early development stages of M. edulis. These findings confirmed earlier hypotheses that CA activity is linked with shell formation (Wilbur and Jodrey 1955; Freeman 1960; Medaković and Lucu 1994; Medaković 1995).

The determination of the CA activity in different soft tissues of adult M. edulis partially confirmed several previous ideas about the role of this enzyme in adult shell biomineralization. Kawai (1955) noted that CA activity in particular tissues of the pearl oyster Pinctada martensii decreased sharply during the first year of life and continued to decrease, though less markedly, during the second and third years of the organism. The decrease in this enzyme activity with age was related to the decreased rate of shell formation. Results of the present study show that CA activity of the mantle edge, which is responsible for shell growth, is not connected with shell length (Fig. 3a), at least in M. edulis.

Also, the CA activity of gonads does not depend on the condition index (Fig. 3b), suggesting that it is not influenced by the quantity and maturity of gametes. All mussels were collected at the same time, so the stage of reproduction should have been the same. There is a connection between CA activity in the mantle edge and the gonad. A high mantle activity is accompanied by low activity in gonads, and vice versa. The low divergences of CA mantle epithelium activities in different size classes of mussels from an average indicate a relatively stable and constant biomineralization process. The results support the hypothesis that CA activity is essential for a rapid shell development but may be insignificant at slow growth (Freeman, 1960).

Acknowledgements The hospitality and facilities at the Biologische Anstalt Helgoland (BAH) were very much appreciated. I am grateful to Professor F. Buchholz, Director of the BAH, for his kind assistance, Professor $\breve{C}$. Lucu for his introduction to carbonic anhydrase determination and valuable intellectual support, and Professor Susan Ford for her helpful advice, critical reading of the manuscript and for improving the English.

\section{References}

Arakawa KY (1980) Prevention and removal of fouling on cultured oysters. A handbook for growers. Maine Sea Grant Tech Rep 56:1-138

Baird RH (1985) Measurement of condition in mussels and oysters. J Cons Int Explor Mer 23:249-257

Bruns W, Dermietzel R, Gros G (1986) Carbonic anhydrase in the sarcoplasmicreticulum of rabbit skeletal muscle. J Physiol (Lond) 371:351-364

Carriker MR, Swann CP, Ewart W (1982) An exploratory study with the proton microprobe of the ontogenetic distribution of 16 elements in the shell of living oysters Crassostrea virginica. Mar Biol 69:235-246

Davenport J, Chen X (1987) A comparison of methods for assessment of condition in the mussel Mytilus edulis L. J Moll Stud 53:293-297

Erlichman JS, Coates EL, Leiter JC (1994) Carbonic anhydrase and $\mathrm{CO}_{2}$ chemoreception in the pulmonate snail Helix aspersa. Respir Physiol 98:27-41

Freeman JA (1960) Influence of carbonic anhydrase inhibitors on shell growth of freshwater snail Physa heterostropha. Biol Bull 118:412-418

Hrs-Brenko M, Calabrese A (1969) The combined effects of salinity and temperature on larvae of the mussel Mytilus edulis. Mar Biol 4:224-226

Kasyanov VL (1984) Planktotrophic larvae of bivalve mollusks: morphology, physiology and behaviour. Biol Morya 10:117128

Kawai DK (1955) Carbonic anhydrase in pearl oyster. II. Changes of the enzyme activity in relation to growth and seasons. Publ Seto Mar Lab (Kyoto Univ) 5:89-94

Kniprath E (1979) The functional morphology of the embryonic shell-gland in the conchiferous molluscs. Malacologia 18:549552

Kniprath E (1981) Ontogeny of the molluscan shell field: a review. Zool Scr 10:61-79

Kulakowski EE, Fliatchinskaya L P (1993) The peculiarities of the larval development. The White Sea's mussels (Mytilus edulis L.). The forming of the regulatory systems elements. In: Suhotkin AA (ed) The investigations on mussel mariculture in the White Sea. Proceedings of the Zoological Institute. Russian Academy of Sciences, St. Petersburg, pp 123-133 
Loosanoff VL, Davies HC (1963) Rearing of bivalve mollusks. Adv Mar Biol 1:1-136

Lutz RA, Kennish MJ (1992) Ecology and morphology of larval and early postlarval mussels. In: Gosling E (ed) The mussel Mytilus: ecology, physiology, genetics and culture. Elsevier, Amsterdam, pp 53-85

Maren TH (1960) A simplified micromethod for the determination of carbonic anhydrase and its inhibitors. J Pharmacol Exp Ther 130:26-29

Medaković D (1995) The calcification processes of larval, juvenile and adult shells of oysters (Ostrea edulis, Linnaeus) and mussels (Mytilus galloprovincialis, Lamarck). $\mathrm{PhD}$ thesis, University of Zagreb and Ruđer Bošković Institute, Zagreb, Croatia

Medaković D, Lucu Č (1994) Distribution of carbonic anhydrase in larval and adult mussels Mytilus edulis Linnaeus. Period Biol 96:452-454

Medaković D, Hrs-Brenko M, Popović S, Gržeta B (1989) X-ray diffraction study of the first larval shell of Ostrea edulis. Mar Biol 101:205-209

Medaković D, Popović S, Gržeta B, Plazonić M, Hrs-Brenko M (1997) X-ray diffraction study of calcification processes in embryos and larvae of the brooding oyster Ostrea edulis. Mar Biol 129:615-623

Miyamoto H, Miyashita T, Okushima M, Nakano S, Morita T, Matsushiro A (1996) A carbonic anhydrase from the nacreous layer in oyster pearls. Proc Natl Acad Sci USA 93:96579660
Nielsen SA, Frieden E (1972) Carbonic anhydrase and growth in the oyster and busycon. Biol Bull (Woods Hole) 98:19-24

Popović S, Gržeta B (1979) The doping method in quantitative X-ray diffraction phase analysis. J Appl Crystallogr 12:205-208

Popović S, Gržeta B, Balić-Žunić T (1983) The doping method in quantitative $\mathrm{X}$-ray diffraction phase analysis. Addendum. J Appl Crystallogr 16:505-507

Strathmann MF (1987) Phylum Mollusca, Class Bivalvia. Reproduction and development of marine invertebrates of the northern Pacific coast. University of Washington Press, Seattle, pp 309-353

Verdonk NH, Cather JN (1983) Morphogenetic determination and differentiation. In: Verdonk NH, van der Biggelaar JAM (eds) The Mollusca. Development. Academic Press, New York, pp 215-252

Waller TR (1981) Functional morphology and development of veliger larvae of the European oyster, Ostrea edulis Linne. Smithson Contrib Zool 328:1-70

Wilbur KM, Anderson NG (1950) Carbonic anhydrase and growth in the oyster and busycon. Biol Bull (Woods Hole) 98:1924

Wilbur KM, Jodrey L (1955) Studies of shell formation. V. The inhibition of shell formation by carbonic anhydrase inhibitors. Biol Bull (Woods Hole) 108:82-112

Wilbur KM, Saleuddin ASM (1983) Shell formation. In: Saleuddin ASM, Wilbur KM (eds) The Mollusca. Physiology. Academic Press, New York, pp 235-287 